\title{
Characterization and Demonstration of the Value of a Lethal Mouse Model of Middle East Respiratory Syndrome Coronavirus Infection and Disease
}

\author{
Xinrong Tao, ${ }^{\text {a Tania Garron, }}{ }^{\text {a }}$ Anurodh Shankar Agrawal, ${ }^{\text {a Abdullah Algaissi, }}{ }^{\text {a,h }}$ Bi-Hung Peng, ${ }^{\text {b }}$ Maki Wakamiya, ${ }^{\mathbf{c}}$ Teh-Sheng Chan, \\ Lu Lu, ${ }^{d}$ Lanying Du, ${ }^{\text {e }}$ Shibo Jiang, ${ }^{\text {e Robert B. Couch, }{ }^{\mathrm{f}} \text { Chien-Te K. Tseng }}{ }^{\mathrm{a}, \mathrm{g}}$ \\ Departments of Microbiology and Immunology a and Pathology, ', Transgenic Mouse Core Facility, Institute for Translational Sciences and Animal Resource Center, \\ Department of Internal Medicine, Division of Infectious Disease, ${ }^{f}$ and Center for Biodefense and Emerging Infectious Disease, ${ }^{g}$ University of Texas Medical Branch, \\ Galveston, Texas, USA; Institute of Medical Microbiology, Fudan University, Shanghai, China ; Lindsley F. Kimball Research Institute, New York Blood Center, New York, \\ New York, USA ; ; Department of Medical Laboratories Technology, College of Applied Medical Sciences, Jazan University, Jazan, Saudi Arabiah
}

\section{ABSTRACT}

Characterized animal models are needed for studying the pathogenesis of and evaluating medical countermeasures for persisting Middle East respiratory syndrome-coronavirus (MERS-CoV) infections. Here, we further characterized a lethal transgenic mouse model of MERS-CoV infection and disease that globally expresses human CD26 (hCD26)/DPP4. The 50\% infectious dose (ID 50 and lethal dose $\left(\mathrm{LD}_{50}\right)$ of virus were estimated to be $<1$ and $10 \mathrm{TCID}_{50}$ of MERS-CoV, respectively. Neutralizing antibody developed in the surviving mice from the $\mathrm{ID}_{50} / \mathrm{LD}_{50}$ determinations, and all were fully immune to challenge with $100 \mathrm{LD}_{50}$ of MERS-CoV. The tissue distribution and histopathology in mice challenged with a potential working dose of $10 \mathrm{LD}_{50}$ of MERS-CoV were subsequently evaluated. In contrast to the overwhelming infection seen in the mice challenged with $10^{5} \mathrm{LD}_{50}$ of MERS-CoV, we were able to recover infectious virus from these mice only infrequently, although quantitative reverse transcription-PCR (qRT-PCR) tests indicated early and persistent lung infection and delayed occurrence of brain infection. Persistent inflammatory infiltrates were seen in the lungs and brain stems at day 2 and day 6 after infection, respectively. While focal infiltrates were also noted in the liver, definite pathology was not seen in other tissues. Finally, using a receptor binding domain protein vaccine and a MERS-CoV fusion inhibitor, we demonstrated the value of this model for evaluating vaccines and antivirals against MERS. As outcomes of MERS-CoV infection in patients differ greatly, ranging from asymptomatic to overwhelming disease and death, having available both an infection model and a lethal model makes this transgenic mouse model relevant for advancing MERS research.

\section{IMPORTANCE}

Fully characterized animal models are essential for studying pathogenesis and for preclinical screening of vaccines and drugs against MERS-CoV infection and disease. When given a high dose of MERS-CoV, our transgenic mice expressing hCD26/DPP4 viral receptor uniformly succumbed to death within 6 days, making it difficult to evaluate host responses to infection and disease. We further characterized this model by determining both the $\mathrm{ID}_{50}$ and the $\mathrm{LD}_{50}$ of MERS-CoV in order to establish both an infection model and a lethal model for MERS and followed this by investigating the antibody responses and immunity of the mice that survived MERS-CoV infection. Using the estimated $\mathrm{LD}_{50}$ and $\mathrm{ID}_{50}$ data, we dissected the kinetics of viral tissue distribution and pathology in mice challenged with $10 \mathrm{LD}_{50}$ of virus and utilized the model for preclinical evaluation of a vaccine and drug for treatment of MERS-CoV infection. This further-characterized transgenic mouse model will be useful for advancing MERS research.

Cevere acute respiratory syndrome (SARS)-coronavirus (SARS-CoV) emerged in Asia in 2002 and spread within months to other countries worldwide, including the United States and Canada, resulting in more than 8,000 cases of severe respiratory illness worldwide with a case mortality rate of $\sim 10 \%$ before the disease was brought under control using infection control measures (1). Ten years later (2012), another new CoV strain emerged in the Middle East as a cause of severe respiratory disease in humans and was named Middle East respiratory syndrome (MERS)-CoV $(2,3)$. In contrast to the apparently high human-to-human transmissibility seen during the short-lived SARS epidemic, MERS infections have continued to occur, especially in the Kingdom of Saudi Arabia, and recently appeared in the Republic of South Korea despite an apparent lower interhuman transmission rate than for SARS (4). As of 3 July 2015, more than 1,365 laboratory-confirmed cases of MERS-CoV disease, including at least 487 related deaths, have been identified globally (http://www.who.int/csr /don/03-july-2015-mers-korea/en/). No vaccines or antivirals 
known to be effective for control of MERS-CoV infection and disease in humans are currently available.

Animal models are needed for study of MERS CoV infection and disease. Nonhuman primates (NHPs), such as rhesus macaques and marmosets, are naturally permissive to MERS-CoV infection and disease $(5,6)$, but they are expensive models of limited availability. Optimal development of knowledge of preventives and treatments for a new infectious disease of humans requires a small-animal model to provide the numbers of animals needed for controlled and extensive studies of pathogenesis and immunity as well as for development of vaccines and antivirals. Mice are the most desirable small animal for this purpose because of availability and the existence of a thorough knowledge base, particularly with respect to genetics and immunology. Unfortunately, the standard small animals (mice, hamsters, and ferrets) all lack the functional MERS-CoV receptor (human CD26 [hCD26]/ DPP4) and are not susceptible to infection (7-9). Three humanized transgenic mouse models, each with strengths and weaknesses, have been reported, aiming to overcome the deficiency of small-animal models that has impaired many aspects of MERS research (10-12). Of the three mouse models that have been described thus far, two are primarily lung infection models that develop various extents of lung pathology in response to $10^{5}$ to $10^{6}$ $50 \%$ tissue culture infectious doses $\left(\right.$ TCID $_{50}$ ) of MERS-CoV but lack morbidity (e.g., weight loss) and mortality, whereas a transgenic mouse model globally expressing human CD26 (hCD26)/ DPP4 that was developed in our laboratory (University of Texas Medical Branch) exhibits acute illness, with profound ( $\geq 20 \%$ ) weight loss, ruffled fur, hunching, squinting, decreased responsiveness to external stimuli, other clinical manifestations, and death seen within days after mice are given an intranasal (i.n.) dose of $10^{6} \mathrm{TCID}_{50}$ of MERS-CoV.

Although these globally expressing hCD26/DPP4 transgenic mice are highly permissive to MERS-CoV infection and disease, the acute onset of severe morbidity and mortality makes it difficult to fully investigate the pathogenesis, host immune responses, and immunity associated with MERS-CoV infection and disease. To further develop this transgenic mouse model for MERS studies, we determined the $50 \%$ lethal dose $\left(\mathrm{LD}_{50}\right)$ and $50 \%$ infectious dose $\left(\mathrm{ID}_{50}\right)$ of MERS-CoV and described the tissue distribution of viral infection and histopathology in the hCD26/DPP4 transgenepositive $\left(\mathrm{Tg}^{+}\right)$mice challenged with a much lower, potential working dose of MERS-CoV. Finally, we show that these transgenic mice can be used as a robust preclinical model for evaluating the efficacy of vaccines and antivirals against MERS.

\section{MATERIALS AND METHODS}

Mice, virus, and cells. Transgenic mice expressing hCD26/DPP4 were generated in house in the barrier facility at the University of Texas Medical Branch as previously described (10). All animal studies were conducted strictly following an approved animal protocol and the guidelines and regulations of the National Institutes of Health and AAALAC. The EMC2012 strain of MERS-CoV, provided by Heinz Feldmann (NIH, Hamilton, MT) and Ron A. Fouchier (Erasmus Medical Center, Rotterdam, The Netherlands), was used throughout the study. Briefly, the MERS-CoV$\mathrm{EMC} / 2012$ strain that we received was designated passage zero (P0) and further expanded with three passages in Vero E6 cells (American Type Culture Collection) for generating cell-free P1, P2, and P3 stocks; P3 was used as the working stock for experiments described in this study. The titers of individual stocks, determined by using Vero E6-based infectivity assays, were expressed as the numbers of $50 \%$ tissue culture infectious doses $\left(\mathrm{TCID}_{50}\right)$ per milliliter. Aliquots of virus stock with an average of $10^{7} \mathrm{TCID}_{50} / \mathrm{ml}$ were stored at $-80^{\circ} \mathrm{C}$.

Viral infections. All of the in vitro and animal studies involving infectious MERS-CoV were conducted within approved biosafety level 3 (BSL-3) and animal BSL-3 laboratories at the National Galveston Laboratory, strictly following approved notification-of-usage (NOU) and animal protocols and the guidelines and regulations of the National Institutes of Health and AAALAC. All of the designs and strategies involving intranasal challenge of $\mathrm{Tg}^{+}$mice with live MERS-CoV in individual experiments were described.

Virus isolations. Collected tissue specimens of lungs, brain, heart, liver, kidney, spleen, and intestine were weighed and homogenized in phosphate-buffered saline (PBS) containing $10 \%$ fetal calf serum (FCS) with a TissueLyser (Qiagen, Retsch, Haan, Germany), as described earlier (10). After clarification of the cellular and tissue debris by centrifugation, the titers of the resulting suspensions of infected tissues were determined in the standard Vero E6 cell-based infectivity assays for quantifying yields of infectious virus. The virus titers of individual samples were expressed as $\log _{10}$ TCID $_{50}$ per gram of tissue.

RNA extraction and real-time RT-PCR. Tissues collected at indicated times were placed in individual vials containing RNAlater solution (Qiagen), weighed, and stored at $4^{\circ} \mathrm{C}$ until used for extracting total RNA. Briefly, tissues were homogenized in $1 \mathrm{ml}$ of TRIzol reagent (Life Technologies) with a TissueLyser. After clarifying by centrifugation at $12,000 \times g$ for $5 \mathrm{~min}$, the resulting suspensions were tested for total RNA and for quantification of MERS-CoV-specific RNA that targeted the upstream E (upE) gene and mouse beta ( $\beta$ )-actin gene (internal control), as described previously (10). Briefly, $0.5 \mu \mathrm{g}$ of RNA extracted from individual tissues was used in a one-step real-time reverse transcription-PCR (RT-PCR) with a set of primers and probes specific for the upE gene of MERS-CoV performed with a Superscript III One-Step RT-PCR kit (Invitrogen) according to the manufacturer's instructions. The primers and probes used for analysis of the upE gene of MERS-CoV were as follows: forward, 5'-GCCTCTACACGGGACCCATA-3'; reverse, 5'-GCAAC GCGC GAT TCA GTT-3'; fluorescence probe, 5' -6-carboxyfluorescein (FAM)/CTCTTCACATAATCGCCCCGAGCTCG/36-5'-carboxytetramethylrhodamine (TAMRA) $/ 3^{\prime}$. The relative amount of targeted mRNA was determined by normalizing with an endogenous control ( $\beta$-actin) gene and expressed as fold change by the standard threshold cycle $\left(\Delta \Delta C_{T}\right)$ method.

Serological assays. MERS-CoV-specific neutralizing antibody and S1 protein-specific IgG antibody responses were quantified by a classical infection reduction assay and a standard enzyme-linked immunosorbent assay (ELISA), respectively, as described previously $(13,14)$. For determining neutralizing antibody titers, the standard Vero E6 cell-based microneutralization assay was used. Briefly, starting at a dilution of $1: 10$, $60-\mu l$ volumes of serial 2-fold dilutions of heat-inactivated serum specimens obtained from surviving $\mathrm{Tg}^{+}$mice at 21 days postinfection (dpi) via retro-orbital bleeding were transferred into duplicate wells of 96-well plates containing $120 \mathrm{TCID}_{50}$ of MERS-CoV at $60 \mu \mathrm{l}$ of M-2 medium/per well, giving a final volume of $120 \mu \mathrm{l} /$ well. The antibody-virus mixtures were incubated at room temperature for $1 \mathrm{~h}$ before transfer of $100 \mu \mathrm{l}$ of the mixtures (containing $100 \mathrm{TCID}_{50}$ of MERS-CoV) into confluent Vero E6 cell monolayers in 96-well plates. Six wells of Vero E6 cells cultured with equal volumes of M-2 medium with and without virus were included in these assays as positive and negative controls, respectively. When the wells of Vero E6 cells infected with virus alone developed advanced cytopathic effects (CPE), the neutralizing capacity of individual serum specimens was determined on the basis of the presence or absence of CPE. Reciprocals of the last dilutions of serum specimens capable of completely preventing the formation of $\mathrm{CPE}$ were used as the neutralizing antibody titers and expressed as $100 \%$ neutralizing titers $\left(\mathrm{NT}_{100}\right)$.

For quantifying the total MERS-CoV S1-specific IgG antibodies, 96well ELISA plates were precoated with recombinant S1-His protein (1 $\mu \mathrm{g} / \mathrm{ml})$, as described previously $(15,16)$. After blocking with Tris-buff- 
ered saline (TBS) containing 10\% FBS and 0.05\% Tween 20 (TBS) for $1 \mathrm{~h}$ at room temperature, $50-\mu$ l volumes of serial 10-fold dilutions of mouse serum specimens, starting at a dilution of 1:100, were added to the plates (Corning; catalog no. 3690), incubated for $1 \mathrm{~h}$ at $37^{\circ} \mathrm{C}$, and thoroughly washed with TBS before addition of horseradish peroxidase (HRP)-conjugated anti-mouse IgG (Southern Biotech; catalog no. 1030-05) (1: $4,000)$ for $1 \mathrm{~h}$ at $37^{\circ} \mathrm{C}$. For quantifying total specific IgG antibodies, the thoroughly washed plates were incubated in the dark with o-phenylenediamine dihydrochloride (Sigma; catalog no. P9187) for $15 \mathrm{~min}$, and the reactions were stopped with $1 \mathrm{~N} \mathrm{H}_{2} \mathrm{SO}_{4}$ and evaluated in an ELISA plate reader (Molecular Device) for measurement of the optical density (OD) at $450 \mathrm{~nm}$. The highest dilutions of serum specimens with MERS-CoV S1specific antibody with a mean OD reading of greater than or equal to 2 standard deviations (SD) greater than the mean for specimens of naive mice were used to define titers.

Histopathology and IHC staining. Tissue specimens harvested from animals at the indicated times after infection were fixed in $10 \%$ buffered formalin for $72 \mathrm{~h}$, transferred to $70 \%$ ethanol, and embedded in paraffin for subsequent sectioning and processing for routine hematoxylin-eosin (H\&E) staining for assessing pathological changes, as described previously (10). For testing for viral antigens in tissues of infected mice, standard alkaline phosphatase-based colorimetric indirect immunohistochemistry (IHC) staining using a combination of a rabbit anti-MERSCoV polyclonal antibody (provided by Heinz Feldmann, NIAID/NIH, through Thomas Ksiazek at UTMB) and a biotinylated swine anti-rabbit immunoglobulin (Dako; catalog no. E0353) was employed as we previously described $(10,17)$. Irrelevant rabbit antibodies were also included in this IHC staining as negative controls. Nuclei were counterstained with Mayer's hematoxylin (Fisher Scientific) before being subjected to microscopic examination.

Vaccine and antiviral evaluations. Groups of age-matched $\mathrm{Tg}^{+}$mice were immunized intramuscularly (i.m.) twice (once and then again three weeks later) with $10 \mu \mathrm{g}$ S377-588-Fc-50 $\mu \mathrm{l}$ PBS formulated with an equal amount of MF59 adjuvant (AddaVax [catalog no. vac-adx-10]; InvivoGen) or with MF59 alone, designated S377-588-Fc/MF59 or PBS/MF59, respectively. Sera of immunized mice after the second immunization were subjected to serological assays for quantifying neutralizing and MERSCoV S1 protein-specific IgG antibodies. Immunized mice were subsequently challenged (i.n.) at day 10 after the second immunization with $10^{3}$ $\mathrm{TCID}_{50}$ of MERS-CoV in a volume of $60 \mu \mathrm{l}$. Three mice in each group were sacrificed at 3 dpi for quantifying infectious virus and viral RNA expression, whereas the remaining five in each group were monitored daily for morbidity (weight loss) and mortality.

Both the preventive efficacy and the therapeutic efficacy of a fusion inhibitor peptide recently proven effective, HR2M6 (18), were evaluated. For measuring the prophylactic potential, groups of $\mathrm{Tg}^{+}$mice were treated (i.n.) with $200 \mu \mathrm{g}$ of HR2M6-50 $\mu \mathrm{l}$ of PBS/per mouse or PBS alone at 1 and/or $4 \mathrm{~h}$ prior to challenge (i.n.) with $100 \mathrm{TCID}_{50}$ of MERS$\mathrm{CoV}$ in $60 \mu \mathrm{l}$. For assessing the therapeutic effect, groups of $\mathrm{Tg}^{+}$mice previously infected (i.n.) with $100 \mathrm{TCID}_{50}$ of MERS-CoV were treated with $50 \mu \mathrm{l}$ of PBS or $200 \mu \mathrm{g}$ of HR2M6-50 $\mu \mathrm{l}$ of PBS at 1, 12, and $24 \mathrm{~h}$ after infection and then once daily until $7 \mathrm{dpi}$. Three mice in each group were sacrificed at 2 dpi for assessing yields of infectious virus or viral RNA in lungs, whereas the remaining five animals in each group were monitored daily for morbidity and mortality.

Statistical analysis. Neutralizing antibody titers and virus titers were averaged for each group of mice. Comparisons were conducted using Student's $t$ test and 1-way analysis of variance as indicated.

\section{RESULTS}

Determination of $\mathrm{LD}_{50}$ and $\mathrm{ID}_{50}$, immune responses, and immunity of hCD26/DPP4 transgenic mice to MERS-CoV infection. To determine the $\mathrm{LD}_{50}$ and $\mathrm{ID}_{50}$, we initially administered (i.n.) serial doses of MERS-CoV, decreasing 10-fold from $10^{6}$ to $10^{1}$ $\mathrm{TCID}_{50}$ in a volume of $60 \mu \mathrm{l}$, to groups of four or eight naive $\mathrm{Tg}^{+}$
TABLE 1 Determining the 50\% lethal dose and 50\% infectious dose of MERS-CoV in hCD26/DPP4 transgenic mice ${ }^{a}$

\begin{tabular}{|c|c|c|c|c|}
\hline Experiment & $\begin{array}{l}\text { Challenge dose } \\
\left(\text { TCID }_{50} /\right. \\
\text { mouse) }\end{array}$ & $\begin{array}{l}\text { No. of deaths/ } \\
\text { no. of challenged } \\
\text { mice }(\%)\end{array}$ & $\begin{array}{l}\text { Day(s) of } \\
\text { death } \\
\text { postchallenge }\end{array}$ & $\begin{array}{l}\text { No. of infected } \\
\text { mice/no. } \\
\text { tested }(\%)^{b}\end{array}$ \\
\hline \multirow[t]{6}{*}{1} & $10^{6}$ & $8 / 8(100)$ & $4-6$ & NA \\
\hline & $10^{5}$ & $4 / 4(100)$ & $5-7$ & NA \\
\hline & $10^{4}$ & $4 / 4(100)$ & $5-8$ & NA \\
\hline & $10^{3}$ & $4 / 4(100)$ & $6-10$ & NA \\
\hline & $10^{2}$ & $8 / 8(100)$ & $6-12$ & NA \\
\hline & $10^{1}$ & $5 / 8(62.5)$ & $8-13$ & ND \\
\hline \multirow[t]{4}{*}{2} & 10 & $2 / 4(50)$ & 9,10 & $2 / 2(100)$ \\
\hline & 5 & $1 / 4(25)$ & 9 & $3 / 3(100)$ \\
\hline & 2.5 & $0 / 4(0)$ & NA & $3 / 4(75)$ \\
\hline & 1.25 & $1 / 4(25)$ & 10 & $3 / 3(100)$ \\
\hline
\end{tabular}

${ }^{a}$ Estimated $\mathrm{LD}_{50}$ and $\mathrm{ID}_{50}$ are 10 and $<1 \mathrm{TCID}_{50}$, respectively. NA, not applicable; ND, not determined.

${ }^{b}$ Infection was determined by analysis of the serum antibody response in neutralization and/or ELISAs.

mice and monitored them daily for clinical manifestations (weight loss) and mortality for at least $21 \mathrm{dpi}$. We found that all mice receiving virus dosages of $10^{2}$ to $10^{6} \mathrm{TCID}_{50}$ of MERS-CoV succumbed to the infection (100\% mortality), with the day of death occurring later with reducing dosage (Table 1$)$. Weight loss was extreme $(\geq 20 \%)$ for dosages of $10^{3}$ and higher; all mice given a dose of $10^{2}$ died, but weight loss was $8 \%$ or less (data not shown). Only 5 of 8 mice given a dose of $10^{1}$ died; deaths occurred between 8 to $13 \mathrm{dpi}$, and weight loss was only $4 \%$ (experiment 1 ; Table 1 ). All of the surviving mice continued to appear healthy up to $21 \mathrm{dpi}$, when the experiment was terminated.

To further assess the $\mathrm{LD}_{50}$ and $\mathrm{ID}_{50}$ of the MERS-CoV stock, we challenged (i.n.) another four groups of four $\mathrm{Tg}^{+}$mice with 2-fold decrements of MERS-CoV doses, starting from $10 \mathrm{TCID}_{50}$; dosages were $10,5,2.5$, and $1.25 \mathrm{TCID}_{50}$ of virus. Mice were followed daily for morbidity (weight loss) and mortality for at least 3 weeks. Although none of the infected mice exhibited any significant weight loss (data not shown), we noted a death on each of days 9 and 10 in mice infected with 10 TCID $_{50}$ and a single death in mice infected with 5 or $1.25 \mathrm{TCID}_{50}$, whereas all mice challenged with $2.5 \mathrm{TCID}_{50}$ of MERS-CoV survived without clinical illness (experiment 2; Table 1). From the data in Table 1, we estimated the $\mathrm{LD}_{50}$ and $\mathrm{ID}_{50}$ of MERS-CoV for this transgenic mouse model to be 10 and $<1 \mathrm{TCID}_{50}$, respectively, further emphasizing the extreme susceptibility of hCD25/DPP4 transgenic mice to MERS$\mathrm{CoV}$ infection and disease.

All but one mouse that survived challenge with the low doses of virus had developed serum neutralizing antibodies and MERSCoV S1 protein-specific IgG antibodies by 21 days following infection, with $\mathrm{NT}_{100}$ and ELISA titers of $1: 10$ to $1: 20$ and $1: 400$ to 1:800, respectively (Table 2 ). We subsequently challenged (i.n.) these low-dose challenge survivors, along with two naive $\mathrm{Tg}^{+}$ mice, with $10^{3} \mathrm{TCID}_{50}\left(100 \mathrm{LD}_{50}\right)$ of MERS-CoV at $35 \mathrm{dpi}$ to determine if they had developed immunity to a lethal infection dose. While the two naive mice simultaneously challenged lost more than $20 \%$ body weight and succumbed to infection within $10 \mathrm{dpi}$, all mice that had survived the prior low-dose challenge, including the one that failed to exhibit a serum antibody response, were immune to a subsequent lethal challenge, surviving without significant weight loss for more than 3 weeks after rechallenge. The rechallenged mouse without serum antibody in the standardized tests did exhibit evidence of neutralizing and ELISA antibody 
TABLE 2 MERS-CoV serum antibody titers in survivors of the initial challenge and their response to rechallenge

\begin{tabular}{|c|c|c|c|c|}
\hline \multirow{2}{*}{$\begin{array}{l}\text { Initial } \\
\text { challenge } \\
\text { dose } \\
\left(\mathrm{TCID}_{50}\right)\end{array}$} & \multirow[b]{2}{*}{$\begin{array}{l}\text { No. of } \\
\text { survivors }\end{array}$} & \multicolumn{2}{|c|}{ Serum antibody responses ${ }^{a}$} & \multirow{2}{*}{$\begin{array}{l}\text { No. of mice that } \\
\text { died or showed } \\
\text { wt loss on } \\
\text { rechallenge/total } \\
\text { no. of mice }^{d}\end{array}$} \\
\hline & & $\begin{array}{l}\text { Neutralizing } \\
\text { antibody }^{b}\end{array}$ & $\begin{array}{l}\text { ELISA IgG } \\
\text { antibody }^{c}\end{array}$ & \\
\hline 10 & 2 & $<10,10$ & 800,800 & $0 / 2$ \\
\hline 5 & 3 & $10,<10,20$ & $800,400,800$ & $0 / 3$ \\
\hline 2.5 & 4 & $20,20,<10,20$ & $400,400,<100,400$ & $0 / 4$ \\
\hline 1.25 & 3 & $<10,10,<10$ & $400,400,400$ & $0 / 3$ \\
\hline
\end{tabular}

${ }^{a}$ Antibody responses were determined at $21 \mathrm{dpi}$.

${ }^{b}$ Data represent the highest dilutions of sera that completely inhibited CPE formation in $100 \%$ of infected Vero E6 cultures $\left(\mathrm{NT}_{100}\right)$.

${ }^{c}$ Data represent the highest dilutions of sera with MERS-CoV S1-specific antibody with a mean optical density (OD) of $\geq 2$ standard deviations (SD) greater than the mean measured for naive mice.

${ }^{d}$ Mice were rechallenged with $100 \mathrm{LD}_{50}\left(10^{3} \mathrm{TCID}_{50}\right)$ of MERS-CoV at day 35 after the initial infection. Two of two simultaneously challenged naive $\mathrm{Tg}^{+}$mice exhibited severe (>20\%) weight loss, and death occurred within 10 dpi.

results for lower-endpoint criteria. Thus, these results indicate that previous infection with a nonlethal dose of MERS-CoV was sufficient to induce immune responses that fully protect $\mathrm{Tg}^{+}$mice against lethal infection.

Kinetics and tissue distribution of viral infection in hCD26/ DPP4 $\mathrm{Tg}^{+}$mice challenged with $10 \mathrm{LD}_{50}$ of MERS-CoV. We have shown that $\mathrm{Tg}^{+}$mice challenged (i.n.) with $10^{6} \mathrm{TCID}_{50}$ of MERS-
CoV suffered a profound weight loss of $\geq 20 \%$, with $100 \%$ death within 6 days after infection. While infectious virus could be readily recovered from the lungs and brains and development of progressive pneumonia, as evidenced by extensive infiltration of inflammatory cells, was seen, no histopathological lesion was identified in brains of infected mice (10). For determining the tissue distribution of viral infection and histopathology over time with a potential working dose of virus, 18 age-matched (10-to-14week-old) $\mathrm{Tg}^{+}$mice were challenged (i.n.) with $10^{2} \mathrm{TCID}_{50}(10$ $\mathrm{LD}_{50}$ ) of MERS-CoV. The initial plan was to sacrifice three mice at $2,4,6,8,10$, and 12 dpi for assessing viral infection in the lungs, brain, heart, liver, kidney, spleen, and intestine by quantifying infectious virus and viral RNA expression using Vero E6 cell-based infectivity and qRT-PCR assays, respectively. Standard immunohistochemistry (IHC) with a rabbit anti-MERS-CoV hyperimmune serum was also performed for detecting viral antigens in tissues.

In contrast to the acute onset of extensive weight loss and mortality seen in $\mathrm{Tg}^{+}$mice infected with a high dose of MERS-CoV, those challenged with a dose of $10 \mathrm{LD}_{50}\left(10^{2} \mathrm{TCID}_{50}\right)$ exhibited a maximum of only $8 \%$ weight loss before dying. We were able to collect tissues from all three animals at 2-day intervals up to $8 \mathrm{dpi}$ but from only a single mouse at $10 \mathrm{dpi}$ and from none at $12 \mathrm{dpi}$ due to infection-associated deaths. In contrast to the consistent recovery of $\geq 10^{7} \mathrm{TCID}_{50} / \mathrm{g}$ of infectious virus from the lungs of mice inoculated with $10^{5} \mathrm{LD}_{50}\left(10^{6} \mathrm{TCID}_{50}\right)$, we detected a much lower titer of virus $\left(\sim 10^{4.6} \mathrm{TCID}_{50} / \mathrm{g}\right)$ from the lung of only a single
A
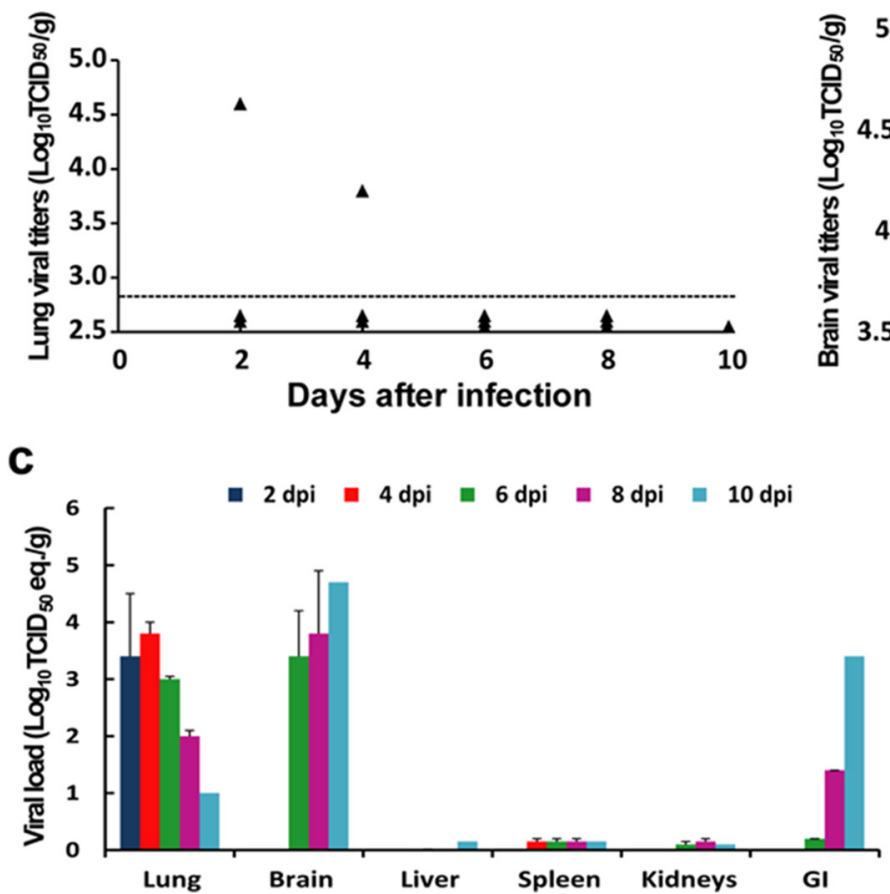

B

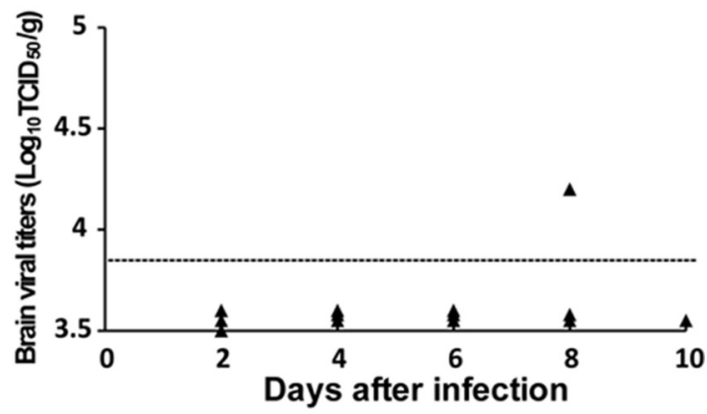

FIG 1 Kinetics and tissue distribution of MERS-CoV infection in hCD26/DPP4 transgenic mice. Eighteen hCD26/DPP4 transgene-positive (Tg ${ }^{+}$) mice were challenged i.n. with $10 \mathrm{LD}_{50}\left(10^{2} \mathrm{TCID}_{50}\right)$ of MERS-CoV/mouse in $50 \mu$ l. Three animals were euthanized at 2 -day intervals starting from 2 dpi for assessing the magnitudes of viral infection in tissues by Vero E6-based infectivity analysis and qRT-PCR targeting the MERS-CoV-specific E gene. (A) Low levels of virus were recovered from infected lung homogenates of a single mouse (of three) at 2 and 4 dpi. Dotted lines represent the limit of detection. (B) A barely detectable level of virus was recovered from brain homogenates of one mouse (of three) at $8 \mathrm{dpi}$. Dotted lines represent the limit of detection. (C) Kinetics of viral loads in various tissue homogenates harvested at the indicated day postinfection, as assessed by levels of upstream E gene-specific viral RNA expression in tissues harvested at the indicated times postinfection, are shown. Data are presented as means \pm standard errors (SE); error bars indicate standard errors. The horizontal dashed lines represent limit of detection. 
mouse at 2 and 4 dpi (Fig. 1A). Also, we detected only approximately $10^{4.2} \mathrm{TCID}_{50} / \mathrm{g}$ of infectious virus from the brain of a single mouse at 8 dpi (Fig. 1B). Additionally, IHC staining with specific rabbit antibodies failed to reveal the expression of viral antigens in paraffin-embedded lung and brain tissues, including those positive for infectious virus (data not shown). All tests over time for infectious virus from other tissues, including liver, spleen, kidneys, and intestines, were negative (data not shown).

Although infectious virus could be detected only sporadically, results of qRT-PCR analyses targeting the upstream E gene of MERS-CoV clearly indicated consistent expression of viral RNA, especially in lungs and brains (Fig. 1C). All lung specimens collected over time were positive for viral RNA, with the highest level detected at $4 \mathrm{dpi}$. In contrast, viral RNA was undetectable in brains until day 6; however, expression increased thereafter, reaching the highest level at $10 \mathrm{dpi}$. Although attempts to isolate virus from the gastrointestinal (GI) tract were unsuccessful, viral RNA expression was detected at day 6 and increased thereafter, reaching a level equivalent to $10^{3.4} \mathrm{TCID}_{50} / \mathrm{g}$ at $10 \mathrm{dpi}$ (Fig. 1C), an increasing trend also observed in $\mathrm{Tg}^{+}$mice challenged earlier with a high dose of virus (10). Viral RNA was detectable in all other tissues over time but at low levels. Taken together, these results indicate that, despite differences in the kinetics and intensities of viral infection, lung, brain, and, possibly GI tracts appear to be the major tissues supporting MERS-CoV infection in $\mathrm{Tg}^{+}$mice.

Histopathology of hCD26/DPP4 transgenic mice infected with $10 \mathrm{LD}_{50}$ of MERS-CoV. In contrast to the profound gross lesions detected solely in the lungs of animals challenged with $10^{6}$ TCID $_{50}$ of MERS-CoV, no gross organ pathology was noted in the lungs, brains, and other organs of animals sacrificed at 2-day intervals for virological and histological evaluations. However, microscopic lesions were noted on different days after infection in lungs, in brains, and, to a lesser extent, in livers but not in other tissues examined, including spleens, kidneys, and small intestines. As shown in Fig. 2, lung histopathology of infected mice primarily showed mild and multifocal perivascular, peribronchial, and interstitial infiltrations with mononuclear cells at 2 and 4 days postinfection (dpi). The intensity of these pulmonary infiltrates was slightly increased in 2 of 3 animals and moderately increased in 1 animal at $6 \mathrm{dpi}$ and reached the maximum in all 3 animals sacrificed at $8 \mathrm{dpi}$. A decreasing trend of the pulmonary inflammatory response was seen in the sole survivor at $10 \mathrm{dpi}$, suggesting that some resolution was under way.

In contrast to the earlier high-dose viral challenge $\left(10^{6}\right.$ $\mathrm{TCID}_{50}$ /mouse), in which an inconsistent mild perivascular effect was the only pathological change seen in infected brains (10), mice infected with $10^{2} \mathrm{TCID}_{50} /$ mouse $\left(10 \mathrm{LD}_{50}\right)$ developed progressive inflammatory responses. As shown in Fig. 3, no abnormalities could be detected in brain stem tissues at either 2 or 4 dpi. However, pathological changes consisting of perivascular cuffing, microglia activation, and apoptotic bodies that likely represent neuronal death were noted in brain stem tissues from 6 to $10 \mathrm{dpi}$. While no intracerebral pathology was seen in brain tissues, mild meningitis was noted in cerebral tissues from 8 to $10 \mathrm{dpi}$.

Focal mononuclear infiltrations were noted in liver specimens collected at 6 to $10 \mathrm{dpi}$ but not in those collected at 2 and $4 \mathrm{dpi}$ (data not shown); however, we did not detect definite pathology in kidney, small intestine, and spleen specimens.

hCD26/DPP4 transgenic mice as a robust preclinical model for development of vaccines and treatment. Having further char- acterized this transgenic mouse lineage with regard to the $\mathrm{LD}_{50}$ and $\mathrm{ID}_{50}$ (Tables 1 and 2), we explored whether it can be used as a small and economical animal model for development of vaccines and treatments for MERS-CoV infection and disease. Since a MERS-CoV receptor binding domain (RBD)-based subunit vaccine (S377-588-Fc) and a fusion inhibitor peptide (HR2M6) have been demonstrated to be preventive and therapeutic candidates for treatment of MERS $(16,19,20)$, we evaluated their efficacy against MERS-CoV infection in our transgenic mice.

For evaluating the efficacy of S377-588-Fc as a subunit vaccine, we first determined its immunogenicity in $\mathrm{Tg}^{+}$mice by measuring serum neutralizing antibody responses. Specifically, two groups of $\mathrm{Tg}^{+}$mice (eight animals in each group) were immunized (i.m.) twice (with 3 weeks between immunizations) with S377-588-Fc plus MF59 adjuvant (S377-588-Fc/MF59) or PBS/MF59 (as a control). Sera of vaccinated mice were collected at day 10 after the second immunization for assessing immunogenicity in neutralizing antibody tests. As shown in Fig. 4, consistent with the absence of any detectable neutralizing antibody response $(<1: 10)$, control mice given PBS/MF59 exhibited $10^{4.9} \mathrm{TCID}_{50} / \mathrm{g}$ of MERS-CoV in lung tissues 2 days after challenge i.n. with $100 \mathrm{LD}_{50}\left(10^{3} \mathrm{TCID}_{50}\right)$ of MERS CoV and profound weight loss ( $\geq 20 \%)$ with $100 \%$ mortality by $8 \mathrm{dpi}$. In contrast, those vaccinated with S377-588-Fc/ MF59 elicited an average serum neutralizing antibody $\left(\mathrm{NT}_{100}\right)$ titer of $\sim 1: 800$. Although none of the three vaccinated and challenged mice tested at $2 \mathrm{dpi}$ had infectious virus in lung specimens, the remaining five vaccinated and challenged mice exhibited mild weight loss and a single death occurred at $10 \mathrm{dpi}$; the remaining four animals recovered from the mild morbidity and survived until the experiment was terminated at $21 \mathrm{dpi}$ (data not shown).

The efficacy of the HR2M6 virus fusion inhibitor was also evaluated in $\mathrm{Tg}^{+}$mice. We initially tested it as a prophylaxis by intranasal administration of a single dose of $200 \mu \mathrm{g}$ HR2M6 or PBS alone at 1 and $4 \mathrm{~h}$ before challenge with $10 \mathrm{LD}_{50}\left(100 \mathrm{TCID}_{50}\right)$ of MERS-CoV. Titers of infectious virus and viral RNA in lungs of three animals sacrificed at 2 dpi were determined by Vero E6based infectivity assays and qRT-PCR, respectively. Although no infectious virus could be recovered from challenged mice regardless of whether they were treated with HR2M6 or not, lung viral RNA titers were significantly reduced from $3.7 \log _{10} \mathrm{TCID}_{50} \mathrm{eq} / \mathrm{g}$ in PBS-treated mice to 1.2 and $1.4 \log _{10} \mathrm{TCID}_{50} \mathrm{eq} / \mathrm{g}$ in those pretreated with HR2M6 at 1 and 4 h, respectively (Fig. 5A). All of the remaining five mice and four of the five mice pretreated with HR2M6 at 1 and $4 \mathrm{~h}$, respectively, were protected from death, whereas four of five PBS-treated mice succumbed to the infection (Fig. 5B). To evaluate the therapeutic efficacy of HR2M6, $\mathrm{Tg}^{+}$ mice previously infected with $10 \mathrm{LD}_{50}\left(10^{2} \mathrm{TCID}_{50}\right)$ of MERSCoV were administered (i.n.) either PBS or $200 \mu$ g of HR2M6 at 1, 12 , and $24 \mathrm{~h}$ and then daily after infection until $7 \mathrm{dpi}$. Three mice were sacrificed at 2 dpi for quantifying viral RNA, whereas the remaining five animals were monitored for morbidity and mortality. In contrast to the earlier report, we did not see any therapeutic benefit of HR2M6 as neither the viral test loads nor the mortality rates were significantly reduced (Fig. 5C and D) $(21,22)$. Results obtained from additional $\mathrm{Tg}^{+}$mice treated with this fusion inhibitor prior to and/or after exposure to different doses of MERS-CoV consistently indicated that HR2M6 was effective as a prophylactic but not as a therapeutic agent against MERS-CoV infection and disease in the $\mathrm{Tg}^{+}$mouse (data not shown). 

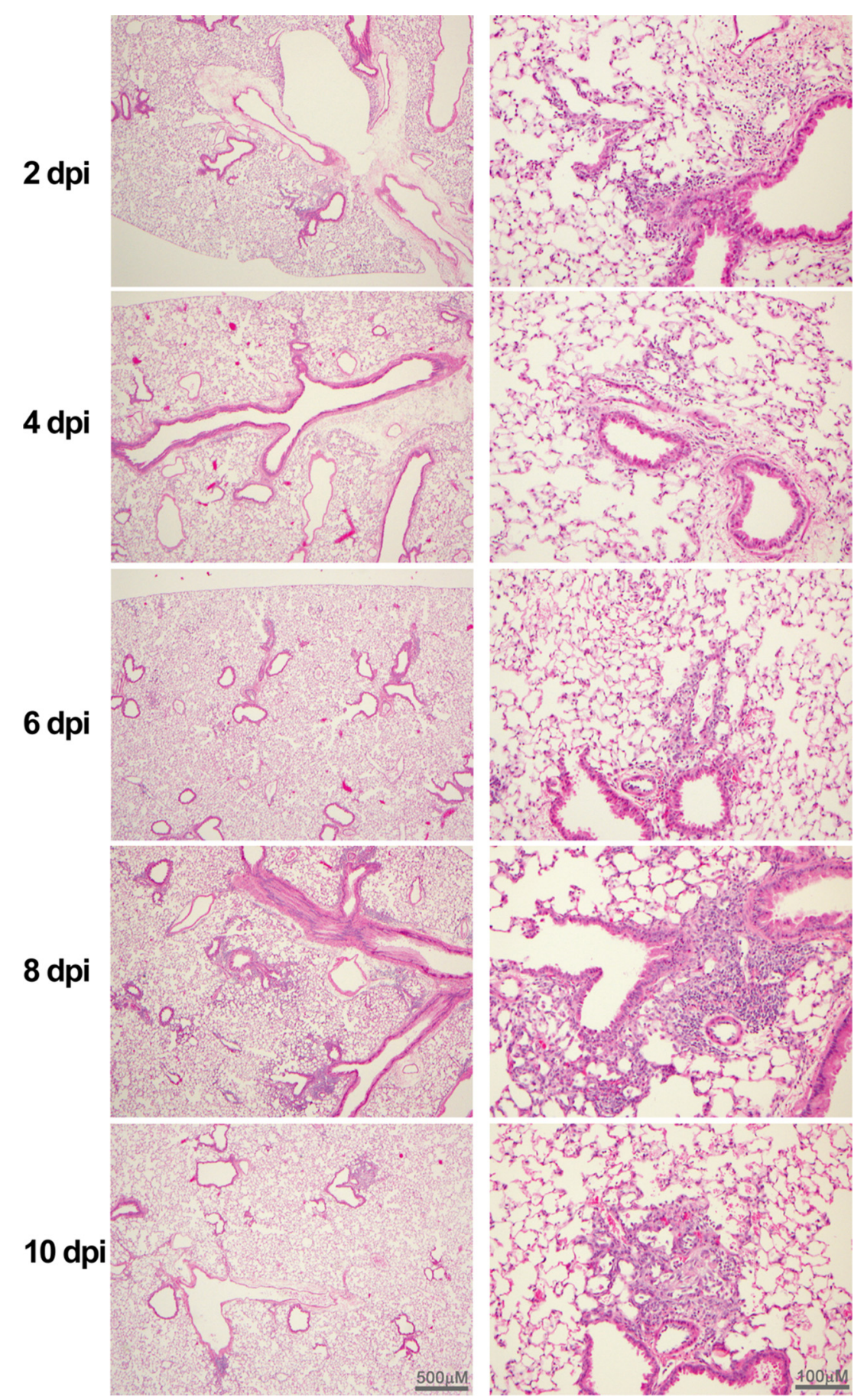

FIG 2 Photomicrographs (taken using low [left panels]- and high [right panels]-power magnification) of lungs of hCD26/DPP4 $\mathrm{Tg}^{+}$mice challenged with 10 $\mathrm{LD}_{50}$ of MERS-CoV. H\&E-stained paraffin-embedded sections of lung specimens collected from $\mathrm{Tg}^{+}$mice at the indicated days after infection were evaluated for pathology as briefly described in Materials and Methods. Multifocal perivascular and peribronchiolar infiltrates predominately composed of mononuclear cells were detected at 2 and 4 dpi. The inflammatory responses gradually increased and extended to bronchi and the alveolar interstitium through 6 to 8 dpi. Some resolution was noted at $10 \mathrm{dpi}$ (in a single surviving mouse), but discrete perivasculitis remained detectable.

\section{DISCUSSION}

Using a cytomegalovirus promoter in a manner previously successful for developing transgenic mouse models of SARS-CoV infection and disease, we identified candidate MERS-CoV-susceptible transgenic mouse lineages (10). One lineage was selected and further evaluated. A $10^{6} \mathrm{TCID}_{50}$ (Vero cell cultures) intranasal dose of MERS-CoV strain EMC/2012 induced severe pneumonia leading to death in 4 to 6 days. Lung virus was highest on day 2 postchallenge, and dissemination to many other organs, including the brain, then ensued (10). Based on RT-PCR assays, virus titer 


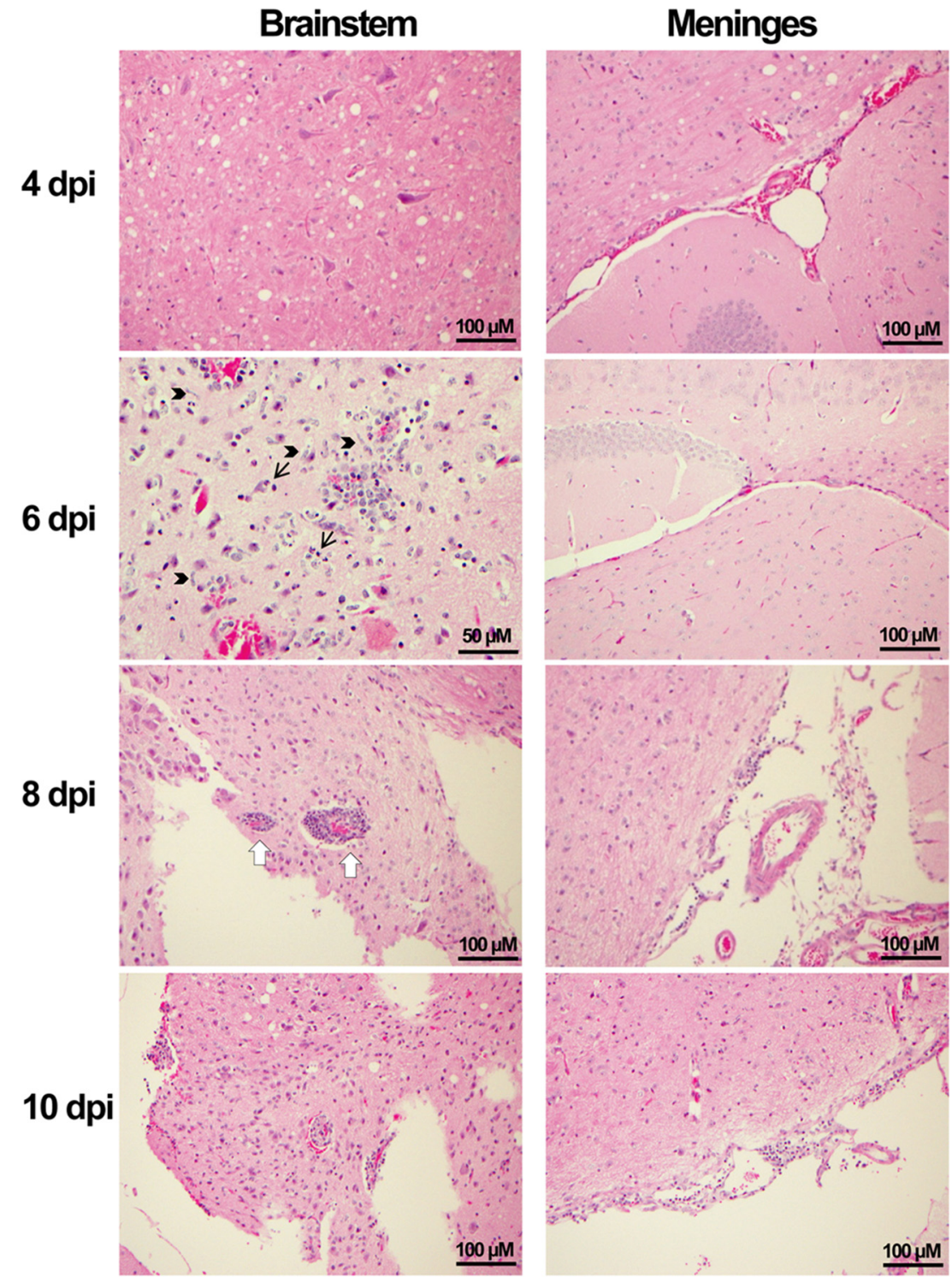

\section{$\kappa:$ apoptotic body s: activated microglia $仓$ : perivascular cuffing}

FIG 3 Photomicrographs (taken using high-power magnification) of brain stem and cortex of hCD26/DPP4 $\mathrm{Tg}^{+}$mice challenged with $10 \mathrm{LD}$ 50 of MERS-CoV. Brain tissues obtained from the infected mice described in the Fig. 2 legend were processed for assessing histopathology. No pathological lesions were seen at 2 and 4 dpi. However, pathological changes, including the presence of perivascular cuffing, apoptotic bodies, and activated microglia, were seen in the brainstem at 6 to $10 \mathrm{dpi}$. No intracerebral pathology was seen, but mononuclear cell collections in cortical meninges were seen at 8 and $10 \mathrm{dpi}$.

was highest in lung on day 2 and brain on day 4 postchallenge. Both extensive gross lung pathology and microscopic lung pathology developed. Of interest is that the lung histopathology was major on day 4 but the brain had minor to no pathology despite detection of high titers of virus and viral antigens in neurons and glial cells. The extensive infection and disease seen with MERS$\mathrm{CoV}$ in this transgenic mouse model was similar to that reported in marmosets challenged with MERS-CoV (6). A concern was that the challenge to our transgenic mice and the challenge to the marmosets might have represented overwhelming doses in very susceptible animals that caused a very severe acute lung infection with dissemination to numerous organs. Although currently available clinical information is inadequate to exclude dissemination of
MERS-CoV as a component of MERS-CoV pneumonia in humans, MERS is considered to be a respiratory infection and disease $(23,24)$.

To clarify the role of challenge dosage in our transgenic mouse model and to provide guidance for study of MERS-CoV infection and disease as well as for evaluation of vaccines and antivirals, we proceeded to conduct infectivity assays in the transgenic mice. These studies yielded an estimated $\mathrm{ID}_{50}$ of $<1 \mathrm{TCID}_{50}$ (Vero cell

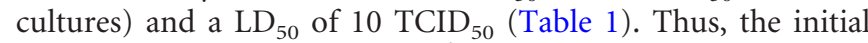
challenge study with a dose of $10^{6} \mathrm{TCID}_{50}$ represented a challenge with more than 1 million $\mathrm{ID}_{50}$ and $100,000 \mathrm{LD}_{50}$ of virus. This might be designated an "overwhelming" dosage and suggests that this may have also been true for the marmoset study (6). 
A

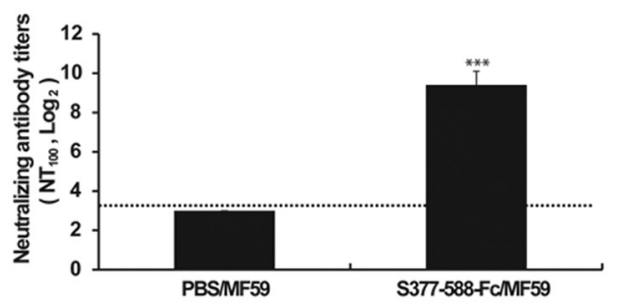

C

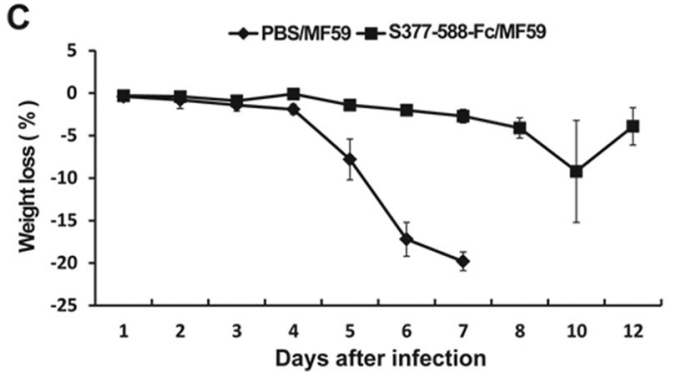

B

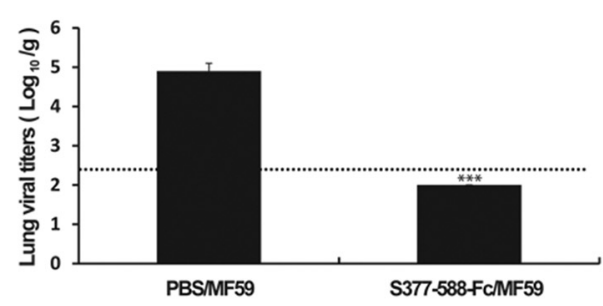

D

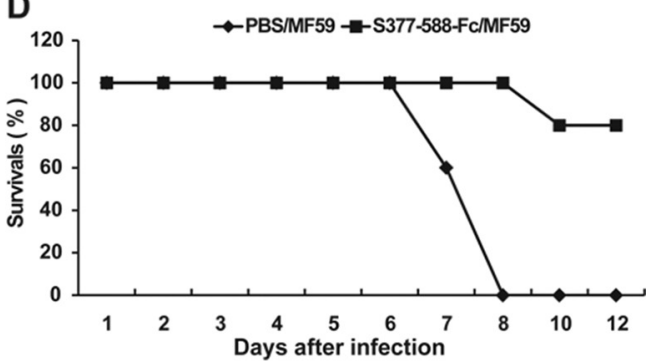

FIG 4 Immunization of hCD26/DDp4 $\mathrm{Tg}^{+}$mice with a receptor binding domain (RBD) and challenge with $100 \mathrm{LD}_{50}$ of MERS-CoV. Two groups of Tg ${ }^{+}$mice (with eight animals in each group) were immunized (once and then again three weeks later) with a MF59-adjuvanted RBD fragment fused with Fc or MF59/PBS alone. (A) Levels of the resulting neutralizing antibody titers were determined prior to viral challenge. (B) Lung viral loads of three animals were determined at day 4 after infection with $100 \mathrm{LD}_{50}\left(10^{3} \mathrm{TCID}_{50}\right)$ of MERS-CoV by qRT-PCR targeting the upstream E gene and were expressed as $\log _{10} \mathrm{TCID}_{50}$ equivalents per gram. (C and D) The remaining five mice in each group were monitored daily for weight loss (C) and survival (D). Error bars indicate standard errors. ${ }^{* *}, P<$ 0.001 (Student's $t$ test for comparisons of results from the control and test groups). The horizontal dashed lines represent limit of detection.

As indicated earlier, two other MERS-CoV mouse infection models with some associated disease have been reported $(11,12)$. The approaches used to provide the human DPP4 receptor were transduction with an adenovirus type 5 vector (Ad5), gene replacement with a commercial procedure (VelociGene), and our transgenic method. While challenge dosages for the 3 models (including our model) in the published data were similar, results of challenge differed considerably. Most striking is that the Ad5 and VelociGene models induced lung infections with some histopathology but little to no clinical disease and no mortality. In contrast, our transgenic model also induced lung infection at about the same level but with severe gross and microscopic pathology, virus dissemination to other organs, including brain, and severe clinical disease preceding death in 4 to 6 days. Tests for dissemination were apparently not done for the Ad5 model and were limited to brain on days 2 and 4 (reported negative) for the VelociGene model. In the present study, using a lower challenge dosage $\left(10 \mathrm{LD}_{50}\right)$, transgenic mice still exhibited dissemination of virus, including to brain, but this was first detected later (6 dpi). Clinical disease occurred but was milder than that seen earlier; however, mortality, although occurring later (days 6 to 12), was still $100 \%$. Mortality was not reported at these later times for the Ad5 model, but the VelociGene model was apparently not followed beyond day 4. In summary, all 3 models appear suitable for studies with desired endpoints of lung virus yield and some lung histopathology. The transgenic models add virus dissemination, severe gross lung pathology and histopathology, and severe clinical disease and mortality as potential endpoints for study. Whether either of the other 2 models would have exhibited the more substantial endpoints with higher challenge dosages, more extensive testing, or longer follow-up is unknown.

On the basis of available data, it seems reasonable to suggest that virus dissemination and infection of other organs may occur during MERS-CoV infections, particularly in those with severe disease. Virus has been detected in blood and urine of a MERS patient (25). Moreover, the receptor for MERS-CoV, CD26/DPP4 (9), is ubiquitous in human tissues and, presumably, in primates and humanized mice; its presence has been demonstrated in lung, kidney, GI tract, brain, and most (if not all) other organs (26). Given access to an organ, virus infection may occur and yield virus and local abnormalities.

Initial reports of SARS emphasized lung disease, its severity, and problems in management (1,27-29). Gastrointestinal infection and disease were reported commonly in early reports as for MERS, but disease in other organs was not. However, subsequent reports of autopsies in cases of SARS-related deaths noted dissemination and a high frequency of central nervous system (CNS) disease, particularly in neurons $(28,30,31)$. It seems possible that an encephalopathy or an encephalitis type of abnormality might have been missed in patients with severe lung disease. In this regard, it is of interest that the reports of infection and disease for the mouse-adapted MA-15 strain of SARS-CoV and the angiotensinconverting enzyme (ACE) receptor transgenic mouse models that were capable of causing severe disease and death in infected mice exhibited SARS-CoV dissemination and presence of virus in the brain (32-34). Thus, SARS-CoV appears to have a capacity for dissemination with infection and disease in other organs, including brain. In a report of three severe cases of CNS disease in association with MERS, the authors suggested that CNS disease might be missed among cases of severe disease in intensive care units with the use of sedation and, sometimes, neuromuscular blockade in the care of patients (35). These findings from SARS-CoV and MERS-CoV infections and diseases in humans suggest a need for caution in drawing conclusions about patterns of human infection and disease until a complete set of data are available. Similarly, data on animal model infections suggest that conclusions 

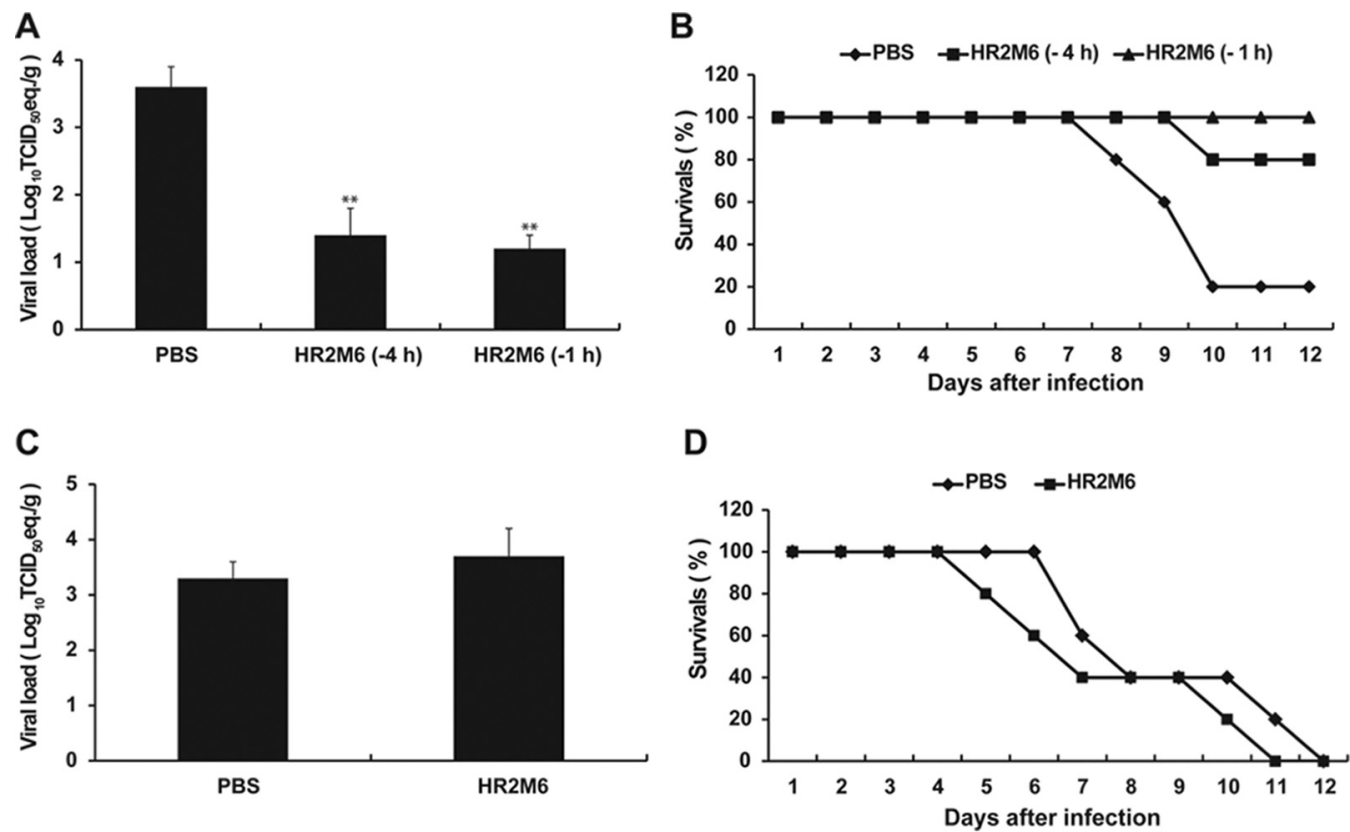

FIG 5 Prophylactic and therapeutic evaluations of the activity of the HR2M6 fusion inhibitor against MERS-CoV infection and disease in hCD26/DPP4 transgenic mice. For evaluating the prophylactic efficacy, groups of $\mathrm{Tg}^{+}$mice (with eight in each group) were given a single dose of either $\mathrm{HR} 2 \mathrm{M} 6$ (200 $\mu \mathrm{g}$ in 60 $\mu \mathrm{l}$ ) or PBS (control) at 1 or $4 \mathrm{~h}$ before viral challenge. Mice were challenged i.n. with $10 \mathrm{LD}_{50}\left(10^{2} \mathrm{TCID}_{50}\right)$ of MERS-CoV in $60 \mu \mathrm{l}$. (A) Lung viral loads were determined in three infected mice per group at 3 dpi by qRT-PCR targeting the upstream E gene and are expressed as $\log _{10}$ TCID $_{50}$ equivalents per gram (eq/g). Error bars indicate standard errors. (B) Survival rates of the remaining five animals in each group were assessed daily. For assessing therapeutic efficacy, two groups of $\mathrm{Tg}^{+}$mice (with eight animals/group) were treated i.n. with HR2M6 (200 $\mu \mathrm{g}$ in $60 \mu \mathrm{l}$ ) or PBS at 1, 12, and $24 \mathrm{~h}$ and then daily for 7 days after infection. $(\mathrm{C}$ and $\mathrm{D})$ Viral challenge experiments were performed with $10 \mathrm{LD}_{50}\left(10^{2} \mathrm{TCID}_{50}\right)$; viral load was assessed at 2 dpi $(\mathrm{C})$, and survival rates (Survivals) were assessed for 12 days (D). ${ }^{* *}, P<0.01$ (1-way analysis of variance [ANOVA] for comparisons with control group results).

about the properties of a model should await a full characterization of the course of infection and disease in the model.

Although further refinement of our transgenic mouse model is desirable, a major value of a small-animal model of infection and disease of humans is in preclinical evaluations of infection and vaccine-induced immunity and of antimicrobials for prevention and treatment. For a test of our model, we conducted a pilot study of immunity induced in surviving mice in the $\mathrm{ID}_{50} / \mathrm{LD}_{50}$ determinations and a preliminary test of a candidate vaccine and antiviral for MERS-CoV. Mice surviving infection had developed serum neutralizing antibody, and all were completely immune to challenge with $100 \mathrm{LD}_{50}$ of MERS-CoV (Tables 1 and 2). Similarly, a receptor binding domain protein vaccine, S377-588-Fc, induced serum neutralizing antibody to MERS-CoV and vaccinated animals were significantly protected from challenge with $100 \mathrm{LD}_{50}$ of virus (Fig. 4). Finally, although no benefit was seen with postchallenge treatment in our test, we verified a previous report that intranasal administration of a MERS-CoV fusion inhibitor peptide, HR2M6, before virus challenge prevented disease and death from challenge (Fig. 5) (18). Thus, the utility of our MERS-CoV model for studies of immunity and for development of vaccines and antivirals has been demonstrated.

Although we have not yet developed a model of infection not leading to death, the $\mathrm{ID}_{50}$ data available for our virus and test system ensure that an effort would be successful. Variations in the severities and patterns of infection and disease in a MERS-CoV model are potentially important, as human infection and disease apparently span a spectrum from infection with little or no disease to overwhelming disease and death $(24,36)$. Currently available data indicate that our transgenic mouse model can completely span this spectrum of infection and disease. To have available both an infection model and a lethal model of MERS-CoV infection is highly desirable.

\section{ACKNOWLEDGMENTS}

We thank Heinz Feldmann, National Institutes of Health at Hamilton, Hamilton, Montana, and Ron A. Fouchier, Erasmus Medical Center at Rotterdam, Rotterdam, The Netherlands, for the MERS CoV.

\section{FUNDING INFORMATION}

NIH provided funding to Chien-Te K. Tseng under grant number R21AI113206-01. Galveston National Laboratory provided funding to Chien-Te K. Tseng under grant number 5UC7AI094660-05.

\section{REFERENCES}

1. Peiris JS, Guan Y, Yuen KY. 2004. Severe acute respiratory syndrome. Nat Med 10:S88-97. http://dx.doi.org/10.1038/nm1143.

2. Assiri A, McGeer A, Perl TM, Price CS, Al Rabeeah AA, Cummings DA, Alabdullatif ZN, Assad M, Almulhim A, Makhdoom H, Madani H, Alhakeem R, Al-Tawfiq JA, Cotten M, Watson SJ, Kellam P, Zumla AI, Memish ZA. 2013. Hospital outbreak of Middle East respiratory syndrome coronavirus. N Engl J Med 369:407-416. http://dx.doi.org/10.1056 /NEJMoa1306742.

3. Guery B, Poissy J, el Mansouf L, Sejourne C, Ettahar N, Lemaire X, Vuotto F, Goffard A, Behillil S, Enouf V, Caro V, Mailles A, Che D, Manuguerra JC, Mathieu D, Fontanet A, van der Werf S. 2013. Clinical features and viral diagnosis of two cases of infection with Middle East respiratory syndrome coronavirus: a report of nosocomial transmission. Lancet 381:2265-2272. http://dx.doi.org/10.1016/S0140-6736(13)60982-4.

4. World Health Organization. 3 June 2015. Summary and risk assessment of current situation in Korea and China. MERS-CoV risk assessment. 
World Health Organization, Geneva, Switzerland. http://www.who.int /csr/disease/coronavirus_infections/risk-assessment-3june2015/en/.

5. de Wit E, Rasmussen AL, Falzarano D, Bushmaker T, Feldmann F, Brining DL, Fischer ER, Martellaro C, Okumura A, Chang J, Scott D, Benecke AG, Katze MG, Feldmann H, Munster VJ. 2013. Middle East respiratory syndrome coronavirus (MERS-CoV) causes transient lower respiratory tract infection in rhesus macaques. Proc Natl Acad Sci U S A 110:16598-16603. http://dx.doi.org/10.1073/pnas.1310744110.

6. Falzarano D, de Wit E, Feldmann F, Rasmussen AL, Okumura A, Peng $\mathrm{X}$, Thomas MJ, van Doremalen N, Haddock E, Nagy L, LaCasse R, Liu T, Zhu J, McLellan JS, Scott DP, Katze MG, Feldmann H, Munster VJ. 2014. Infection with MERS-CoV causes lethal pneumonia in the common marmoset. PLoS Pathog 10:e1004250. http://dx.doi.org/10.1371/journal .ppat.1004250.

7. Coleman CM, Matthews KL, Goicochea L, Frieman MB. 2014. Wildtype and innate immune-deficient mice are not susceptible to the Middle East respiratory syndrome coronavirus. J Gen Virol 95:408 - 412. http://dx doi.org/10.1099/vir.0.060640-0.

8. de Wit E, Prescott J, Baseler L, Bushmaker T, Thomas T, Lackemeyer MG, Martellaro C, Milne-Price S, Haddock E, Haagmans BL, Feldmann H, Munster VJ. 2013. The Middle East respiratory syndrome coronavirus (MERS-CoV) does not replicate in Syrian hamsters. PLoS One 8:e69127. http://dx.doi.org/10.1371/journal.pone.0069127.

9. Raj VS, Smits SL, Provacia LB, van den Brand JM, Wiersma L, Ouwendijk WJ, Bestebroer TM, Spronken MI, van Amerongen G, Rottier PJ, Fouchier RA, Bosch BJ, Osterhaus AD, Haagmans BL. 2014. Adenosine deaminase acts as a natural antagonist for dipeptidyl peptidase 4-mediated entry of the Middle East respiratory syndrome coronavirus. J Virol 88:1834-1838. http://dx.doi.org/10.1128/JVI.02935-13.

10. Agrawal AS, Garron T, Tao X, Peng BH, Wakamiya M, Chan TS, Couch RB, Tseng CT. 2015. Generation of a transgenic mouse model of Middle East respiratory syndrome coronavirus infection and disease. J Virol 89: 3659-3670. http://dx.doi.org/10.1128/JVI.03427-14.

11. Pascal KE, Coleman CM, Mujica AO, Kamat V, Badithe A, Fairhurst J, Hunt C, Strein J, Berrebi A, Sisk JM, Matthews KL, Babb R, Chen G, Lai KM, Huang TT, Olson W, Yancopoulos GD, Stahl N, Frieman MB, Kyratsous CA. 2015. Pre- and postexposure efficacy of fully human antibodies against Spike protein in a novel humanized mouse model of MERS-CoV infection. Proc Natl Acad Sci U S A 112:8738-8743. http://dx .doi.org/10.1073/pnas.1510830112.

12. Zhao J, Li K, Wohlford-Lenane C, Agnihothram SS, Fett C, Gale MJ, Jr, Baric RS, Enjuanes L, Gallagher T, McCray PB, Jr, Perlman S. 2014. Rapid generation of a mouse model for Middle East respiratory syndrome. Proc Natl Acad Sci U S A 111:4970-4975. http://dx.doi.org/10.1073/pnas 1323279111.

13. Du L, Kou Z, Ma C, Tao X, Wang L, Zhao G, Chen Y, Yu F, Tseng CT, Zhou Y, Jiang S. 2013. A truncated receptor-binding domain of MERS$\mathrm{CoV}$ spike protein potently inhibits MERS-CoV infection and induces strong neutralizing antibody responses: implication for developing therapeutics and vaccines. PLoS One 8:e81587. http://dx.doi.org/10.1371 /journal.pone.0081587.

14. Tseng CT, Sbrana E, Iwata-Yoshikawa N, Newman PC, Garron T, Atmar RL, Peters CJ, Couch RB. 2012. Immunization with SARS coronavirus vaccines leads to pulmonary immunopathology on challenge with the SARS virus. PLoS One 7:e35421. http://dx.doi.org/10.1371/journal .pone.0035421.

15. Ma C, Wang L, Tao X, Zhang N, Yang Y, Tseng CT, Li F, Zhou Y, Jiang S, Du L. 2014. Searching for an ideal vaccine candidate among different MERS coronavirus receptor-binding fragments-the importance of immunofocusing in subunit vaccine design. Vaccine 32:6170-6176. http: //dx.doi.org/10.1016/j.vaccine.2014.08.086.

16. Zhang N, Channappanavar R, Ma C, Wang L, Tang J, Garron T, Tao X, Tasneem S, Lu L, Tseng CT, Zhou Y, Perlman S, Jiang S, Du L. 2 February 2015, posting date. Identification of an ideal adjuvant for receptor-binding domain-based subunit vaccines against Middle East respiratory syndrome coronavirus. Cell Mol Immunol http://dx.doi.org/10.1038 /cmi.2015.03

17. Tao X, Mei F, Agrawal A, Peters CJ, Ksiazek TG, Cheng X, Tseng CT. 2014. Blocking of exchange proteins directly activated by cAMP leads to reduced replication of Middle East respiratory syndrome coronavirus. J Virol 88:3902-3910. http://dx.doi.org/10.1128/JVI.03001-13.

18. Channappanavar R, Lu L, Xia S, Du L, Meyerholz DK, Perlman S, Jiang S. 8 June 2015, posting date. Protective effect of intranasal regimens con- taining peptidic Middle East respiratory syndrome coronavirus fusion inhibitor against MERS-CoV infection. J Infect Dis http://dx.doi.org/10 .1093/infdis/jiv325.

19. Tang J, Zhang N, Tao X, Zhao G, Guo Y, Tseng CT, Jiang S, Du L, Zhou Y. 2015. Optimization of antigen dose for a receptor-binding domain-based subunit vaccine against MERS coronavirus. Hum Vaccin Immunother 11: 1244-1250. http://dx.doi.org/10.1080/21645515.2015.1021527.

20. Wang L, Shi W, Joyce MG, Modjarrad K, Zhang Y, Leung K, Lees CR, Zhou T, Yassine HM, Kanekiyo M, Yang ZY, Chen X, Becker MM, Freeman M, Vogel L, Johnson JC, Olinger G, Todd JP, Bagci U, Solomon J, Mollura DJ, Hensley L, Jahrling P, Denison MR, Rao SS, Subbarao K, Kwong PD, Mascola JR, Kong WP, Graham BS. 2015. Evaluation of candidate vaccine approaches for MERS-CoV. Nat Commun 6:7712. http://dx.doi.org/10.1038/ncomms8712.

21. Gao J, Lu G, Qi J, Li Y, Wu Y, Deng Y, Geng H, Li H, Wang Q, Xiao H, Tan W, Yan J, Gao GF. 2013. Structure of the fusion core and inhibition of fusion by a heptad repeat peptide derived from the S protein of Middle East respiratory syndrome coronavirus. J Virol 87:1313413140. http://dx.doi.org/10.1128/JVI.02433-13.

22. Lu L, Liu Q, Zhu Y, Chan KH, Qin L, Li Y, Wang Q, Chan JF, Du L, Yu F, Ma C, Ye S, Yuen KY, Zhang R, Jiang S. 2014. Structure-based discovery of Middle East respiratory syndrome coronavirus fusion inhibitor. Nat Commun 5:3067.

23. Zaki AM, van Boheemen S, Bestebroer TM, Osterhaus AD, Fouchier RA. 2012. Isolation of a novel coronavirus from a man with pneumonia in Saudi Arabia. N Engl J Med 367:1814-1820. http://dx.doi.org/10.1056 /NEJMoa1211721.

24. Zumla A, Hui DS, Perlman S. 3 June 2015, posting dateMiddle East respiratory syndrome. Lancet http://dx.doi.org/10.1016/S0140-6736(15) 60454-8.

25. Drosten C, Seilmaier M, Corman VM, Hartmann W, Scheible G, Sack S, Guggemos W, Kallies R, Muth D, Junglen S, Muller MA, Haas W, Guberina H, Rohnisch T, Schmid-Wendtner M, Aldabbagh S, Dittmer U, Gold H, Graf P, Bonin F, Rambaut A, Wendtner CM. 2013. Clinical features and virological analysis of a case of Middle East respiratory syndrome coronavirus infection. Lancet Infect Dis 13:745-751. http://dx.doi .org/10.1016/S1473-3099(13)70154-3.

26. Gorrell MD. 2005. Dipeptidyl peptidase IV and related enzymes in cell biology and liver disorders. Clin Sci 108:277-292. http://dx.doi.org/10 $.1042 /$ CS20040302.

27. Denison MR. 2004. Severe acute respiratory syndrome coronavirus pathogenesis, disease and vaccines: an update. Pediatr Infect Dis J 23: S207-S214. http://dx.doi.org/10.1097/01.inf.0000144666.95284.05.

28. Ding Y, He L, Zhang Q, Huang Z, Che X, Hou J, Wang H, Shen H, Qiu L, Li Z, Geng J, Cai J, Han H, Li X, Kang W, Weng D, Liang P, Jiang S. 2004. Organ distribution of severe acute respiratory syndrome (SARS) associated coronavirus (SARS-CoV) in SARS patients: implications for pathogenesis and virus transmission pathways. J Pathol 203:622-630. http://dx.doi.org/10.1002/path.1560.

29. Nicholls JM, Poon LL, Lee KC, Ng WF, Lai ST, Leung CY, Chu CM, Hui PK, Mak KL, Lim W, Yan KW, Chan KH, Tsang NC, Guan Y, Yuen KY, Peiris JS. 2003. Lung pathology of fatal severe acute respiratory syndrome. Lancet 361:1773-1778. http://dx.doi.org/10.1016/S0140-6736(03)13413-7.

30. Gu J, Gong E, Zhang B, Zheng J, Gao Z, Zhong Y, Zou W, Zhan J, Wang S, Xie Z, Zhuang H, Wu B, Zhong H, Shao H, Fang W, Gao D, Pei F, Li X, He Z, Xu D, Shi X, Anderson VM, Leong AS. 2005. Multiple organ infection and the pathogenesis of SARS. J Exp Med 202:415-424. http://dx.doi.org/10.1084/jem.20050828.

31. Xu J, Zhong S, Liu J, Li L, Li Y, Wu X, Li Z, Deng P, Zhang J, Zhong N, Ding Y, Jiang Y. 2005. Detection of severe acute respiratory syndrome coronavirus in the brain: potential role of the chemokine mig in pathogenesis. Clin Infect Dis 41:1089-1096. http://dx.doi.org/10.1086/444461.

32. McCray PB, Jr, Pewe L, Wohlford-Lenane C, Hickey M, Manzel L, Shi L, Netland J, Jia HP, Halabi C, Sigmund CD, Meyerholz DK, Kirby P, Look DC, Perlman S. 2007. Lethal infection of K18-hACE2 mice infected with severe acute respiratory syndrome coronavirus. J Virol 81:813-821. http://dx.doi.org/10.1128/JVI.02012-06

33. Roberts A, Deming D, Paddock CD, Cheng A, Yount B, Vogel L, Herman BD, Sheahan T, Heise M, Genrich GL, Zaki SR, Baric R, Subbarao K. 2007. A mouse-adapted SARS-coronavirus causes disease and mortality in BALB/c mice. PLoS Pathog 3:e5. http://dx.doi.org/10 .1371/journal.ppat.0030005.

34. Tseng CT, Huang C, Newman P, Wang N, Narayanan K, Watts DM, 
Makino S, Packard MM, Zaki SR, Chan TS, Peters CJ. 2007. Severe acute respiratory syndrome coronavirus infection of mice transgenic for the human angiotensin-converting enzyme 2 virus receptor. J Virol 81:11621173. http://dx.doi.org/10.1128/JVI.01702-06.

35. Arabi YM, Harthi A, Hussein J, Bouchama A, Johani S, Hajeer AH, Saeed BT, Wahbi A, Saedy A, AlDabbagh T, Okaili R, Sadat M, Balkhy
H. 20 January 2015, posting dateSevere neurologic syndrome associated with Middle East respiratory syndrome corona virus (MERS-CoV). Infection http://dx.doi.org/10.1007/s15010-015-0720-y.

36. Al-Tawfiq JA. 2013. Middle East respiratory syndrome-coronavirus infection: an overview. J Infect Public Health 6:319-322. http://dx.doi.org /10.1016/j.jiph.2013.06.001. 